\title{
Bibliography
}

\section{SOURCES AND EDITIONS OF SOUTHWELL'S WORK}

The following information is largely taken from James H. McDonald and Nancy Pollard Brown (eds), The Poems of Robert Southwell, S.J. (Oxford: Clarendon Press, 1967). For information on the manuscripts the reader is recommended to see this edition or Peter Davidson and Anne Sweeney (ed. and intro.), The Collected Poems of S. Robert Southwell S.J. (Manchester: Carcanet, forthcoming).

\section{Editions}

Saint Peters Complaint, With other Poemes

Wolfe, 1595a STC 22957 (March)

Wolfe, 1595b STC 22957 (by 5 April)

Cawood, 1595 STC 22956 (entered on Stationers' Register 5 April)

Cawood, 1597 STC 22958 (based on Cawood, 1595)

Cawood, 1599 STC 22959 (based on Cawood, 1597)

Waldegrave, ?1599 STC 22960 (Scotland; based on Wolfe, 1595b)

Cawood, 1602 STC 22960a (some new material, based on Cawood, 1599)

Leake, ?1608 STC 22961 (corr., based on Cawood, 1602)

Barrett, $16_{15}$ STC 22962

Wreittoun, 1634 STC 22967 (Scotland; based on Barrett, 1615)

\section{Moeoniae}

(Busby, 1595a; and Busby, 1595b) STC 22955 (augmented from Folger MS)

(Busby, 1595c) STC 22954 (augmented from Folger MS)

\section{'Collected' works}

St Omer, 1616 STC 22963 (some new material ('WS', 'cosen', etc.); based on Cawood, 1602)

St Omer, 1620 STC 22964 (revsd.; first full identification of Southwell, S.J.)

Barrett, 1620 STC 22965 (Anglicanised; first 'complete' works)

Haviland, 1630 STC 22966 (2nd edn. of Barrett, 1620)

Haviland, 1634-36 STC 22968 (as Haviland, 1630)

Prose works

The Triumphs over Death (Busby, London, 1595) STC 22971

An Epistle of Comfort (printed secretly in England, 1587-88) STC 22946

Marie Magdalens Funeral Teares (Cawood, London, 1591) STC 29950 


\section{More recent editions}

Poetry

Alexander B. Grosart (ed.), The Complete Poems of Robert Southwell, S.J. (London: Robson, Fuller Worthies' Library, 1872)

James H. McDonald, and Nancy Pollard Brown (eds), The Poems of Robert Southwell, S.J. (Oxford: Clarendon Press, 1967)

Peter Davidson and Anne Sweeney (ed. and intro.), The Collected Poems of S. Robert Southwell S.J. (Manchester: Carcanet, forthcoming)

Prose

An Epistle of Comfort (London: secretly printed, 1587); repr., ed. D. M. Rogers, English Recusant Literature, 1538-1640 (London: Scolar Press, 1974), vol. 211

'An Epistle of Robert Southwell unto His Father' (1589), in Two Letters and Short Rules of a Good Life, ed. Nancy Pollard Brown (Charlottesville: University Press of Virginia, for the Folger Shakespeare Library, 1973)

An Humble Supplication to Her Majestie, ed. R. C. Bald (Cambridge: Cambridge University Press, 1953)

Marie Magdalens Funeral Teares (London: Gabriel Cawood, 1591); repr., ed. Vincent B. Leitch (New York: Delmar, 1975)

Spiritual Exercises and Devotions, ed. J. M. de Buck and trans. P. E. Hallett (London: Sheed and Ward, 1931)

The Triumphs over Death, ed. J. W. Trotman (London: Manresa Press, 1914)

\section{Southwell's letters}

\section{Sources}

The Jesuit Archives, Rome (Fondo Gesuitico, 651); Annual Letters of the English College, Rome

\section{Editions and collections}

Nancy Pollard Brown (ed.), Robert Southwell, S.J.: Two Letters and Short Rules of a Good Life (Charlottesville: University Press of Virginia, for the Folger Shakespeare Library, 1973)

Henry Foley, S.J., Records of the English Province of the Society of Jesus, 7 vols (London: Burns and Oates, 1877), I, 301-87

Thomas M. McCoog, S.J., English and Welsh Jesuits, 1555-1650, Publications of the Catholic Record Society Series, 74-75 ([London]: Catholic Record Society, 1994-95)

Anthony G. Petti (ed.), The Letters and Dispatches of Richard Verstegan, c.1550-1640, Publications of the Catholic Record Society Series, 52 (London: Catholic Record Society, 1959)

John Hungerford Pollen, S.J. (ed.), Unpublished Documents Relating to the English Martyrs, I (1584-1603), Publications of the Catholic Record Society Series, 5 (1903) ([London]: Catholic Record Society, 1908), pp. 293-333 


\section{OTHER PRINTED SOURCES}

Alabaster, William, Sonnets, ed. G. M. Story and Helen Gardner (Oxford: Oxford University Press, 1959)

Allison, Anthony, and D. M. Rogers, The Contemporary Printed Literature of the English Counter-Reformation Between 1558 and 1640, 2 vols (Aldershot: Scolar Press, 1989-94)

Alpers, Paul, 'Spenser's Domain of Lyric', in Hugh Maclean and Anne Lake Prescott (eds), Edmund Spenser's Poetry, 3rd edn (New York: Norton, 1968), pp. $787-96$

Althusser, Louis, 'Ideology and the State', in Lenin and Philosophy and Other Essays, trans. B. Brewster (London: New Left Books, 1977)

Arber, Edward (ed.), A Transcript of the Registers of the Company of Stationers of London 1554-1640 AD, 5 vols (London: privately printed, 1875-94)

Ault, Norman (ed.) Elizabethan Lyrics (New York: Capricorn, 1960)

Bacon, Francis, Major Works, ed. Brian Vickers (Oxford: Oxford University Press, 1996)

Bailey, Gauvin Alexander, Between Renaissance and Baroque: Jesuit Art in Rome, 1565-1610 (Toronto: University of Toronto Press, 2003)

“"Le style jésuite n'existe pas": Jesuit Corporate Culture and the Visual Arts', in John W. O’Malley, S.J., Gauvin Alexander Bailey, et al., The Jesuits: Cultures, Sciences, and the Arts 1540-1773 (Toronto: University of Toronto Press, 1999), pp. $38-89$

'The Truth-Showing Mirror: Jesuit Catechism and the Arts in Mughal India', in John W. O’Malley, S.J., Gauvin Alexander Bailey, et al., The Jesuits: Cultures, Sciences, and the Arts 1540-1773 (Toronto: University of Toronto Press, 1999), pp. 380-401

Bakhtin, Mikhail, Rabelais and His World, trans. Hélène Iswolsky (Cambridge, MA: MIT Press, 1968)

Baldwin, T. W., William Shakespeare Adapts a Hanging (Princeton, NJ: Princeton University Press, 1931)

- William Shakespeare's Small Latine and Lesse Greeke (Urbana: University of Illinois Press, 1944)

Barker, Frances, The Tremulous Private Body: Essays on Subjection (London: Methuen, 1984)

— and Jay Bernstein, et al. (eds), 1642: Literature and Power in the Seventeenth Century (Colchester: University of Essex, 1981)

Barroll, Leeds, Politics, Plague and Shakespeare's Theatre (Ithaca, NY: Cornell University Press, 1991)

Bate, Jonathan, Shakespeare and Ovid (Oxford: Clarendon Press, 1993)

Bath, Michael, Speaking Pictures: English Emblem Books and Renaissance Culture (London: Longman, 1994)

Batley, Karen, The Genius of Shakespeare (London: Picador, 1997)

_ 'Southwell's "New Heaven, New Warre”', Explicator, 53 (Fall, 1994), 7-10

Baudrillard, Jean, 'The Evil Demon of Images', Mari Kuttna Memorial Lecture Series, 1 (Sydney: University of Sydney, Power Institute of Fine Arts, 1987)

Beal, Peter, Index of English Literary Manuscripts, 2 vols (London: Mansel, 198093), I (1450-1623) (1980) 
Bellarmine, St Roberto, Cardinal, S.J., De gemitu columbae, sive, De bono lacrymarum, 3 vols (Antwerp: Ex Officina Plantiniana; Moretos, 1617)

Du Bellay, Joachim, La Defence, et illustration de la Langue Francoyse (Angevin: 1549)

Belsey, Catherine, The Subject of Tragedy (London: Routledge, 1985)

Berry, Philippa, Shakespeare's Feminine Endings: Disfiguring Death in the Tragedies (London: Routledge, 1999)

Bevington, David M., From Mankind to Marlowe (Cambridge, MA: Harvard University Press, 1962)

Black, J. B., The Reign of Elizabeth, 1558-1603, Oxford History of England Series (Oxford: Clarendon Press, 1959)

Bossy, John, The English Catholic Community 1570-1850 (London: Darton, Longman \& Todd, 1975)

'The Heart of Robert Persons', in Thomas M. McCoog, S.J. (ed.), The Reckoned Expense: Edmund Campion and the Early English Jesuits (Woodbridge: Boydell, 1996), pp. $141-58$

'The Society of Jesus in the Wars of Religion', in Judith Loades (ed.) Monastic Studies: The Continuity of Tradition (Bangor: Headstart History, 1990), pp. 22944

Van den Broecke, Marcel P. R., Ortelius Atlas Maps: An Illustrated Guide ('t Goy: HES Publishers, 1996)

Brown, Cedric C. (ed.), Patronage, Politics, and Literary Traditions in England 15581658 (Detroit: Wayne State University Press, 1993)

— and Arthur F. Marotti (eds), Text and Cultural Change in Early Modern England (Basingstoke: Macmillan, 1997)

Brown, John (ed.), John Bunyan: Grace Abounding to the Chief of Sinners (Cambridge: Cambridge University Press, 1907)

Brown, Nancy Pollard, 'Robert Southwell: the Mission of the Written Word', in Thomas M. McCoog, S.J. (ed.), The Reckoned Expense: Edmund Campion and the Early English Jesuits (Woodbridge: Boydell, 1996), pp. 193-214

- (ed.), Robert Southwell, S.J.: Two Letters and Short Rules of a Good Life, (Charlottesville: University Press of Virginia, for the Folger Shakespeare Library, 1973)

Brown, Rawdon (ed.), Calendar of State Papers and Manuscripts Relating to English Affairs, Venetian, 1202- [1675] (London: Longmans, 1864-1947)

Brownlow, F. W., 'Richard Topcliffe: Elizabeth's Enforcer and the Representation of Power in King Lear', in Richard Dutton, Alison Findlay, and Richard Wilson (eds), Lancastrian Shakespeare: Theatre and Religion (Manchester: Manchester University Press, 2003), pp. 161-78

— Robert Southwell, Twayne's English Authors Series, 516 (New York: Simon \& Schuster Macmillan, 1996)

Bruno, Giordano, The Heroic Frenzies, trans. Paul Eugene Memmo, University of North Carolina Studies in Romance Languages and Literatures Series, 50 (Chapel Hill; Valencia printed: University of North Carolina Press, 1964)

Bulfinch, Thomas, Mythology (New York: Avenel, 1978)

Bullough, Geoffrey (ed.), Narrative and Dramatic Sources of Shakespeare, 8 vols (London: Routledge and Kegan Paul, 1957-75)

Byrd, William, Collected Works: Psalms, Sonnets and Songs (1588), ed. Edmund H. Fellowes (London: Stainer \& Bell, 1965) 
Calvin, John, Institutes of the Christian Religion, trans. Henry Beveridge, 3 vols (Edinburgh: Calvin Translation Society, 1845-46; repr. Grand Rapids: Eerdmans, 1983)

Campbell, Roy, The Poems of St John of the Cross (Harmondsworth: Penguin, 1960)

Caraman, Philip, S.J., A Study in Friendship: Saint Robert Southwell and Henry Garnet (Saint Louis, MO: The Institute of Jesuit Sources, 1995)

— ed., and trans., John Gerard, S.J.: The Autobiography of an Elizabethan (London: Longmans, Green, 1951)

Carey, John, ed., John Donne (Oxford: Oxford University Press, 1990)

Carroll, Michael P., Catholic Cults and Devotions: A Psychological Enquiry (Kingston, Montreal: McGill-Queen's University, 1989)

Cavalli, Vittorio F., 'St Robert Southwell, S.J.: a Selective Bibliographic Supplement to the Studies of Pierre Janelle and James H. McDonald', Renaissance History, 21.3 (1993), 297-304

Cheney, Patrick, Spenser's Famous Flight: A Renaissance Idea of a Literary Career (Toronto: University of Toronto Press, 1993)

Cixous, Hélène, 'Laugh of the Medusa', in Robyn R. Warhol and D. P. Herndl (eds), Feminisms: An Anthology of Literary Theory and Criticism (New Brunswick: Rutgers University Press, 1991), 335-49

Cleri, Bonita (ed.), Federico Zuccari: le idée, gli scritti: atti del convegno di Sant'Angelo in Vado (Milan: Electa (Pesaro), Provincia di Pesaro e Urbino, 1997)

Collinson, Patrick, The Elizabethan Puritan Movement (London: Cape, 1967)

Corthell, Ronald, 'Robert Persons and the Writer's Mission', in Arthur F. Marotti (ed.), Catholicism and Anti-Catholicism (London: Macmillan, 1999), pp. 35-62

Craik, T. W. (ed.), Sir Philip Sidney, Selected Poetry and Prose (London: Methuen, 1965)

Cressy, David, Education in Tudor and Stuart England (London: Edward Arnold, 1975)

Croft, P. J., Autograph Poetry in the English Language: Facsimiles of Original Manuscripts from the Fourteenth to the Twentieth Century, 2 vols (London: Cassell, 1973)

Cust, Richard, and Ann Hughes (eds), Conflict in Early Stuart England: Studies in Religion and Politics 1603-1642 (Harlow: Longmans, 1989)

Davidson, Clifford, 'Robert Southwell: Lyric Poetry, the Restoration of Images, and Martyrdom', Ben Jonson Journal, 7 (2000), 157-86

Davidson, Peter, 'Archives of the British Province of the Society of Jesus', unpublished conference paper, Recusant Archives and Remains from the Three Kingdoms 1560-1789: Catholics in Exile at Home and Abroad (Downside Abbey, 2004)

_ 'Emblems for the Vulnerata, Valladolid, September 1600' (unpublished conference paper, 2003)

Davidson, Peter et al., 'Festivals of the New World: the viceroyalties of Mexico and Peru', in J. R. Mulryne, Helen Watanabe-O’Kelly, and Margaret Shewring (eds), Europa Triumphans, Court and Civic Festivals in Early Modern Europe (Aldershot: MHRA in association with Ashgate, 2004), II, pp. 345-9.

Devlin, Christopher, Hamlet's Divinity and Other Essays (London: Hart-Davis, 1963) The Life of Robert Southwell Poet and Martyr (London: Longmans, Green, 1956) 
Dillon, Anne, The Constitution of Martyrdom in the English Catholic Community, 1535-1603 (Aldershot: Ashgate, c.2002)

'Praying by Number: the Confraternity of the Rosary and the English Catholic Community, c.1580-1700', History, 88 (July 2003), 451-71

Dollimore, Jonathan, Radical Tragedy: Religion, Ideology and Poetry in the Drama of Shakespeare and his Contemporaries, 2nd edn (Brighton: Harvester Wheatsheaf, 1989)

Donne, John, Pseudo-Martyr (London, 1610)

Douay, English College, The First and Second Diaries of the English College, Douay, trans. Thomas Francis Knox (London: Nutt, 1878; repr. Farnborough: Gregg, 1969)

Duffy, Eamon, 'Bare Ruined Choirs: Remembering Catholicism in Shakespeare's England', in Richard Dutton, Alison Findlay, and Richard Wilson (eds), Lancastrian Shakespeare: Theatre and Religion (Manchester: Manchester University Press, 2003), pp. 40-57

- The Stripping of the Altars: Traditional Religion in England c.1400-1580 (New Haven: Yale University Press, 1992)

Duncan-Jones, Katherine, Shakespeare's Sonnets (London: Arden Shakespeare, 1997)

_ 'Sir Philip Sidney's Debt to Edmund Campion', in Thomas M. McCoog, S.J. (ed.), The Reckoned Expense: Edmund Campion and the Early English Jesuits (Woodbridge: Boydell, 1996), pp. 85-102

— (ed.), Sir Philip Sidney (Oxford: Oxford University Press, 1989)

Dutton, Richard, 'Licensing and Censorship', in David Scott Kastan (ed.), A Companion to Shakespeare (Oxford: Blackwell, 1999), pp. 377-91

- Mastering the Revels: The Regulation and Censorship of English Renaissance Drama (Iowa City: University of Iowa Press, 1991)

- William Shakespeare (London: Macmillan, 1989)

- (ed.), Ben Jonson, Longman Critical Reader Series (Harlow: Pearson, 2000) and Jean E. Howard (eds), A Companion to Shakespeare's Works, II (Oxford: Blackwell, 2003)

Elizabeth I, Collected Works, ed. Leah S. Marcus, Janel Mueller, and Mary Beth Rose (Chicago, IL: University of Chicago Press, 2000)

Elton, G. R. (ed.), The Tudor Constitution: Documents and Commentary, and edn (Cambridge: Cambridge University Press, 1982)

Fenlon, Dermot, Heresy and Obedience in Tridentine Italy: Cardinal Pole and the Counter-Reformation (Cambridge: Cambridge University Press, 1972)

Finch, M. E., 'The Wealth of Five Northamptonshire Families', Northamptonshire Record Society, 19 (1956) [no page nos]

Flynn, Dennis, “'Out of Step”: Six Supplementary Notes on Jasper Heywood', in Thomas M. McCoog, S.J. (ed.), The Reckoned Expense: Edmund Campion and the Early English Jesuits (Woodbridge: Boydell, 1996), pp. 179-92

Foley, Henry, S.J., Records of the English Province of the Society of Jesus, 7 vols (London: Burns and Oates, 1877)

Fraser, Antonia, Mary Queen of Scots (London: Panther, 1970)

Ganss, George E., Saint Ignatius' Idea of a Jesuit University, 2nd edn (Milwaukee: Marquette University Press, 1956)

Gardner, Helen, The Metaphysical Poets, 2nd rev. edn (Harmondsworth: Penguin, 1985) 
- (ed.), John Donne: The Divine Poems (Oxford: Clarendon Press, 1952)

Garnet, Henry, The Societie of the Rosary, wherein is conteined the beginning, increase Q p profit of the same. Also the orders and manifold graces annexed unto it, with divers other things thereunto appertaining (n.p.d. [London, 1593-94])

Gerard, John, S.J., The Autobiography of an Elizabethan, trans. and ed. Philip Caraman, S.J. (London: Longmans, Green, 1951)

Gerard, John, Catalogus arborum (London: exofficina Arnoldii Hatfield, impensis Ioannis Norton, 1599)

Gibson, T. E., Crosby Records (Manchester: Chetham Society, 1887)

Green, Mary Anne Everett (ed.), Calendar of State Papers, Domestic Series, of the Reign of Elizabeth, 1581-1590 (London: Longmans, 1865)

- Calendar of State Papers, Domestic Series, of the Reign of Elizabeth, 1591-1594 (London: HMSO, 1867; repr. Liechtenstein: Kraus, 1967)

Greenblatt, Stephen, Hamlet in Purgatory (Princeton, NJ: Princeton University Press, 2001)

_ Renaissance Self-Fashioning: From More to Shakespeare (Chicago: University of Chicago Press, 1980)

- Shakespearean Negotiations: The Circulation of Social Energy in Renaissance England (Oxford: Clarendon Press, 1997)

Greg, W. W., Some Aspects and Problems of London Publishing (Oxford: Oxford Clarendon Press, 1956)

Gregerson, Linda, The Reformation of the Subject: Spenser, Milton, and the English Protestant Epic (Cambridge: Cambridge University Press, 1997)

Grosart, Alexander B., A Bower of Delights; being interwoven Verse and Prose from the works of Nicholas Breton (London: Elliot Stock, 1893)

- Complete Works in Verse and Prose of Samuel Daniel, 5 vols (New York: Russell \& Russell, 1963)

— (ed.), The Complete Poems of Robert Southwell, S.J. (London: Robson, Fuller Worthies' Library, 1872)

Guy, John, My Heart Is My Own: The Life of Mary Queen of Scots (London: Harper Collins, 2004)

Hackett, Helen, Virgin Mother, Maiden Queen: Elizabeth I and the Cult of the Virgin Mary (Basingstoke: Macmillan, 1995)

Hadfield, Andrew, The English Renaissance 1500-1620 (Oxford: Blackwell, 2001)

Haigh, Christopher, 'The Continuity of Catholicism in the English Reformation', in Christopher Haigh (ed.), The English Reformation Revised (Cambridge: Cambridge University Press, 1987), pp. 176-215

- English Reformations: Religion, Politics and Society under the Tudors (Oxford: Clarendon Press, 1993)

Hamilton, Bernice, Political Thought in Sixteenth Century Spain: A Study of the Political Ideas of Vitoria, De Solo, Suárez and Molina (Oxford: Clarendon Press, 1963)

Hanson, Elizabeth, Discovering the Subject in Renaissance England (Cambridge: Cambridge University Press, 1998)

Happold, F. C., Mysticism: A Study and an Anthology (Harmondsworth: Penguin, 1990)

Headlam-Wells, Robin, Spenser's Faerie Queene and the Cult of Elizabeth (London: Croom Helm, 1983) 
Hedley, Jane, Power in Verse: Metaphor and Metonymy in the Renaissance Lyric (University Park; London: Pennsylvania State University Press, 1988)

Helgerson, Richard, 'Shakespeare and Contemporary Dramatists of History', in Richard Dutton and Jean E. Howard (eds), A Companion to Shakespeare's Works, 4 vols (Oxford: Blackwell, 2003), II, pp. 26-47

Heninger, S. K., Jr, Touches of Sweet Harmony: Pythagorean Cosmology and Renaissance Poetics (San Marino, CA: Huntington Library, 1974)

Hermann-Fiore, Kristina, 'Gli angeli, nella teoria e nella pittura di Federico Zuccari', in Bonita Cleri (ed.), Federico Zuccari: le idée, gli scritti: atti del convegno di Sant'Angelo in Vado (Milan: Electa (Pesaro), Provincia di Pesaro e Urbino, 1997), pp. 90-107

Hertz, Alexandra, 'Imitators of Christ: The Martyr-Cycles of Late Sixteenth Century Rome Seen in Context', Storia dell'Arte, 62 (1988), 53-70

Hill, Geoffrey, 'The Absolute Reasonableness of Robert Southwell', in The Lords of Limit (New York: Oxford University Press, 1984)

'Tenebrae', Collected Poems, Penguin International Poets Series (Harmondsworth; Penguin, 1990)

Hirn, Yrjö, The Sacred Shrine: A Study of the Poetry and Art of the Catholic Church, and edn, rev. C. H. Talbot (London: Faber \& Faber, 1958)

Höltgen, Karl Josef, 'Henry Hawkins: A Jesuit Writer and Emblematist in Stuart England', in John W. O’Malley, S.J., Gauvin Alexander Bailey, et al., The Jesuits: Cultures, Sciences, and the Arts 1540-1773 (Toronto: University of Toronto Press, 1999) pp. 601-26

Honan, Park, Shakespeare, a Life (Oxford: Oxford University Press, 1998)

Honigmann, E. A. J., Shakespeare: The 'Lost Years', 2nd edn (Manchester: Manchester University Press, 1998)

Hood, Christobel M., The Book of Robert Southwell (Oxford: Blackwell, 1926)

Houliston, Victor, 'Brevis Dialogismus: An Anonymous Becket Play from the Jesuit Seminary at St Omer', English Literary Renaissance, 23 (1993), 382-427

'Why Robert Persons Would Not Be Pacified: Edmund Bunny's Theft of The Book of Resolution', in Thomas M. McCoog, S.J. (ed.), The Reckoned Expense: Edmund Campion and the Early English Jesuits (Woodbridge: Boydell, 1996), pp. $159-78$

Huffman, Clifford Chalmers, Elizabethan Impressions: John Wolfe and his Press, AMS Studies in the Renaissance Series, 21 (New York: AMS, 1988)

Hughes, Gerard W., S.J., In Search of a Way: Two Journeys of Spiritual Discovery (London: Darton Longman \& Todd, 1998)

Hughes, Philip, The Reformation of England, rev. 5th edn, 3 vols (New York: Macmillan, 1963)

Hughes, Thomas, S.J., The Educational System of the Jesuits (London: Heinemann, 1904)

Hutchison, F. E. (ed.), George Herbert: Works (Oxford: Clarendon Press, 1941)

Ignatius of Loyola, S.J., St, The Autobiography: With Related Documents, ed., intro. and notes John C. Olin, trans. Joseph F. O'Callaghan (London: Harper and Row, 1974)

_ Letters, selected and trans. William J. Young, S.J. (Chicago, IL: Loyola University Press, 1959)

The Spiritual Exercises and Selected Works, ed. George E. Ganss (New York: Paulist Press, c.1991) 
Ingleby, C. M., et al., The Shakespeare Allusion-Book, 2 vols (London: Oxford University Press, 1932)

Isham, Sir Gyles, Sir Thomas Tresham and his Buildings, Northamptonshire Antiquarian Society, Reports and Papers Series (Northampton: Northamptonshire Antiquarian Society, 1966), vol. 65 (1964, 1965), Part 2 [no page nos]

Janelle, Pierre, Robert Southwell the Writer: A Study in Religious Inspiration (London: Sheed and Ward, 1935)

Jones, Emrys (ed.), The New Oxford Book of Sixteenth Century Verse (Oxford: Oxford University Press, 1991)

Jonsen, Albert R., and Stephen Toulmin, The Abuses of Casuistry: A History of Moral Theology (Berkeley and Los Angeles: University of California Press, 1988)

Jonson, Ben, Works, ed. C. H. Herford, and P. and E. Simpson, 8 vols (Oxford: Clarendon Press, 1925-52)

Kastan, David Scott (ed.), A Companion to Shakespeare (Oxford: Blackwell, 1999)

Keene, Dennis (ed.), Henry Howard, Earl of Surrey: Selected Poems (Manchester: Carcanet, 1985)

Kerman, Joseph, The Masses and Motets of William Byrd (London: Faber \& Faber, 1981) Kermode, Frank, Shakespeare's Language (Harmondsworth: Penguin, 2000)

King, John N., English Reformation Literature: The Tudor Origins of the Protestant Tradition (Princeton, NJ: Princeton University Press, 1982)

Klebanoff, Randi, 'The Vita and the Morte: Making the Sacred in Renaissance Bologna'; paper delivered at the Sixteenth Century Studies Conference (Toronto, 24 October 1998)

Knox, R. A., Enthusiasm: A Chapter in the History of Religion (Oxford: Clarendon Press, 1950)

Knox, Thomas Francis, trans., The First and Second Diaries of the English College, Douay (London: Nutt, 1878; repr. Farnborough: Gregg, 1969)

Kuchar, Gary, 'Southwell's "A vale of teares”: A Psychoanalysis of Form', Mosaic, 34.1 (2001), 107-20

Lake, Peter, 'Religious Identities in Shakespeare's England', in David Scott Kastan (ed.), A Companion to Shakespeare (Oxford: Blackwell, 1999), pp. 57-84

Larocca, John J., S.J., 'Popery and Pounds: The Effect of the Jesuit Mission on Penal Legislation', in Thomas M. McCoog, S.J. (ed.), The Reckoned Expense: Edmund Campion and the Early English Jesuits (Woodbridge: Boydell, 1996), pp. $249-64$

Lewalski, Barbara Kiefer, Protestant Poetics and the Seventeenth Century Religious Lyric (Princeton, NJ: Princeton University Press, 1979)

Lewis, C. S., Allegory of Love (Oxford: Oxford University Press, 1936)

- English Literature in the Sixteenth Century excluding Drama (Oxford: Clarendon Press, 1944)

-Studies in Medieval and Renaissance Literature, coll. Walter Hooper (Cambridge: Cambridge University Press, 1966)

Loades, David, 'The Spirituality of the Restored Catholic Church (1553-1558) in the Context of the Counter Reformation', in Thomas M. McCoog, S.J. (ed.), The Reckoned Expense: Edmund Campion and the Early English Jesuits (Woodbridge: Boydell, 1996), pp. 3-20

Lodge, David, and Nigel Wood (eds), Modern Criticism and Theory: A Reader, and edn (Harlow: Pearson Educational, 1988) 
Lynch, Michael, Mary Stuart: Queen in Three Kingdoms (Oxford: Blackwell, 1988) MacCulloch, Diarmaid, Thomas Cranmer: A Life (New Haven: Yale University Press, 1996)

MacGrath, Patrick, and Joy Rowe, 'Anstruther Analysed: The Elizabethan Seminary Priests', Recusant History, 18.1 (May 1986), 1-13

Maclean, Hugh, and Anne Lake Prescott (eds), Edmund Spenser's Poetry, 3rd edn (New York: Norton, 1968)

Maritain, Jacques, An Introduction to Philosophy, trans. E. I. Watkins (London: Sheed and Ward, 1979)

Marotti, Arthur F., (ed.), Catholicism and Anti-Catholicism in Early Modern English Texts (Basingstoke: Macmillan, 1999)

- Manuscript, Print and the English Renaissance Lyric (Ithaca: Cornell University Press, 1995)

Martin, Patrick H., and John Finnis, "Thomas Thorpe, "W.S.," and the Catholic Intelligencers', English Literary Renaissance, 33 (2003), 3-43

Martz, Louis L., The Poetry of Meditation (New Haven: Yale University Press, 1954) Mayer, Thomas F., 'A Test of Wills: Cardinal Pole, Ignatius Loyola, and the Jesuits in England', in Thomas M. McCoog, S.J. (ed.), The Reckoned Expense: Edmund Campion and the Early English Jesuits (Woodbridge: Boydell, 1996), pp. 21-38

McConica, James, 'The Catholic Experience in Tudor Oxford', in Thomas M. McCoog, S.J. (ed.), The Reckoned Expense: Edmund Campion and the Early English Jesuits (Woodbridge: Boydell, 1996), pp. 39-66

McCoog, Thomas M., S.J. (ed), The Mercurian Project: Forming Jesuit Culture 15721580 (Rome: Institutum Historicum Societatis Iesu, 2004)

_ "Playing the Champion": The Role of Disputation in the Jesuit Mission', in Thomas M. McCoog, S.J. (ed.), The Reckoned Expense: Edmund Campion and the Early English Jesuits (Woodbridge: Boydell, 1996), pp. 119-41

- (ed.), The Reckoned Expense: Edmund Campion and the Early English Jesuits (Woodbridge: Boydell, 1996)

McDonald, James H., and Nancy Pollard Brown (eds), The Poems of Robert Southwell, S.J. (Oxford: Clarendon Press, 1967)

McEachern, Claire, The Poetics of English Nationhood 1590-1612 (Cambridge: Cambridge University Press, 1996)

McInerny, Ralph, Art and Prudence: Studies in the Thought of Jacques Maritain, Publications of the Jacques Maritain Center Series, 1 ([n.p.]: University of Notre Dame Press, c.1988)

Medina, Francisco de Borja, S.J., 'Intrigues of a Scottish Jesuit at the Spanish Court: Unpublished Letters of William Crichton to Claudio Acquaviva (Madrid 1590-1592)', in Thomas M. McCoog, S.J. (ed.), The Reckoned Expense: Edmund Campion and the Early English Jesuits (Woodbridge: Boydell, 1996), pp. 215-98

Meissner, W. W., Ignatius of Loyola: The Psychology of a Saint (New Haven: Yale University Press, 1992)

Melchiori, Giorgio, Shakespeare's Dramatic Meditations: An Experiment in Criticism (Oxford: Clarendon Press, 1976)

Meyer, A. O., England und die katholische Kirche unter Elisabeth, Bibliothek des Kgl. Preussischen Historischen Instituts in Rom Series, 6, 2 vols (Rome: Loescher, 1911)

Milward, Peter, S.J., 'Shakespeare's Jesuit Schoolmasters', in Richard Dutton, 
Alison Findlay, and Richard Wilson (eds), Lancastrian Shakespeare: Theatre and Religion (Manchester: Manchester University Press, 2003), pp. 58-70 - Shakespeare's Religious Background (London: Sidgwick and Jackson, 1973) Milton, Anthony, 'Qualified Intolerance: The Limits and Ambiguities of Early Stuart Anti-Catholicism', in Arthur F. Marotti (ed.), Catholicism and Anti-Catholicism in Early Modern English texts (Basingstoke: Macmillan, 1999), pp. 85-109

Montrose, Louis A., 'Of Gentlemen and Shepherds: The Politics of Elizabethan Pastoral Form', Elizabethan Literary History, 50 (1983), 415-60

More, Henry, Historia Missionis Anglicanae Societatis Jesu (St Omer, 1660)

Morris, J., Troubles of Our Catholic Forefathers, 3 vols (Farnborough: Gregg, 1970)

Muir, Kenneth, The Sources of Shakespeare's Plays (London: Methuen, 1977)

Munday, Anthony, The English Roman Life, ed. Philip Ayres (Oxford: Clarendon Press, 1980)

Murdin, William (ed.), A Collection of State Papers relating to Affairs in the Reign of Elizabeth, 1571-1596, transcribed from original papers and other authentic memorials left by W. Cecill Lord Burghley, and reposited in the Library at Hatfield House (London: William Bowyer, 1759)

Murphy, Andrew (ed.), The Renaissance Text: Theory, Editing, Textuality (Manchester: Manchester University Press, 2000)

Neill, Michael, Issues of Death: Mortality and Identity in English Renaissance Tragedy (Oxford: Clarendon Press, 1997)

De Nicolás, Antonio T., Ignatius de Loyola: Powers of Imagining (Albany: State University of New York Press, 1986)

Nicoll, Allardyce (ed.), Shakespeare in his own Age (Cambridge: Cambridge University Press, 1976)

Norbrook, David, Poetry and Politics in the English Renaissance (London: Routledge and Kegan Paul, 1984)

O'Callaghan, Michelle, The 'Shepheards Nation': Jacobean Spenserians and Early Stuart Political Culture, 1612-1625 (Oxford: Clarendon Press, 2000)

O'Connell, Robert J., Art and the Christian Intelligence in St Augustine (Oxford: Blackwell, 1978)

O’Malley, John W., The First Jesuits (Cambridge, MA: Harvard University Press, 1993)

- S.J., and Gauvin Alexander Bailey, et al., The Jesuits: Cultures, Sciences, and the Arts 1540-1773 (Toronto: University of Toronto Press, 1999)

Ong, Walter, Fighting for Life: Contest, Sexuality and Consciousness (Ithaca: Cornell University Press, 1981)

Ousby, Ian (ed.), Cambridge Guide to Literature in English (Cambridge: Cambridge University Press, 1988)

Oxley, Brian, 'The Relation between Robert Southwell's Neo-Latin and English Poetry', Recusant History 17.3 (May 1985), 201-7

Palgrave, Francis T., The Golden Treasury: Selected from the Best Songs and Lyrical Poems in the English Language and Arranged with Notes, with a Supplementary Fifth Book Selected, Arranged, and Annotated by Laurence Binyon, 3rd edn (London: Macmillan, 1939)

Palmer, Alan and Veronica, Who's Who in Shakespeare's England (London: Methuen, 1999)

Partridge, A. C. (ed.), The Tribe of Ben: Pre-Augustan Classical Verse in English (Columbia: University of South Carolina Press, 1970) 
Patrides, C. A. (ed.), Sir Thomas Browne: The Major Works (Harmondsworth: Penguin, 1977)

Patterson, Annabel M., Censorship and Interpretation: The Conditions of Writing and Reading in Early Modern England (Madison, WI: University of Wisconsin Press, 1984)

Peers, E. Allison, trans. and ed., The Complete Works of St Teresa of Jesus, 3 vols (London: Sheed and Ward, 1946)

Petti, Anthony G., The Letters and Dispatches of Richard Verstegan, Publications of the Catholic Record Society Series, 52 (London: Catholic Record Society, 1959)

Pieper, Josef, Only the Lover Sings: Art and Contemplation, trans. Lothar Krauth (San Francisco: Ignatius Press, 1990)

Pilarz, Scott, S.J., Robert Southwell and the Mission of Literature 1561-1595: Writing Reconciliation (Aldershot: Ashgate, 2004)

Pincombe, Mike (ed.), The Anatomy of Tudor Literature: Proceedings of the First International Conference of the Tudor Symposium (1998) (Aldershot: Ashgate, 2001)

Pollard, A. F., and G. R. Redgrave (eds), A Short-title Catalogue of Books Printed in England, Scotland, and Ireland, and of English Books Printed Abroad, 1475-1640 (London: Bibliographical Society, 1926)

Pollen, John Hungerford, S.J., Acts of the English Martyrs hitherto unpublished (London: Burns and Oates, 1891)

- Unpublished Documents Relating to the English Martyrs, Publications of the Catholic Record Society Series, 5 (London: Catholic Record Society, 1908) 'Father Robert Southwell and the Babington Plot', The Month 119 (1911), 302-4

_ 'Religious Terrorism under Queen Elizabeth', The Month, 105.489 (March 1905), 271-87

Porges-Watson, Elizabeth (ed.), Sir Philip Sidney: Defence of Poesie, Astrophil and Stella, and Other Writings (London: Dent, 1997)

Praz, Mario, 'Baroque in England', Modern Philology, 61 (1963/4), 169-79

— 'Robert Southwell's "Saint Peters Complaint” and its Italian source', Modern Language Review, 3 (July, 1924), 273-90

Pritchard, Arnold, Catholic Loyalism in Elizabethan England (Chapel Hill: University of North Carolina Press, c.1979)

Puppi, Lionello, Torment in Art: Pain, Violence and Martyrdom (New York: Rizzoli, 1991)

Puttenham, George, The Arte of English Poesie, ed. Gladys Doidge Willcock, and Alice Walker (London: R. Field, 1589; repr. London: Cambridge University Press, 1970)

Questier, Michael, Conversion, Politics and Religion in England, 1580-1625 (Cambridge: Cambridge University Press, 1996)

“"Like Locusts over all the World": Conversion, Indoctrination and the Society of Jesus in Late Elizabethan and Jacobean England', in Thomas M. McCoog, S.J. (ed.), The Reckoned Expense: Edmund Campion and the Early English Jesuits (Woodbridge: Boydell, 1996), pp. 265-84

Raspa, Anthony, The Emotive Image: Jesuit Poetics in the English Renaissance (Fort Worth: Texas Christian University Press, 1983)

Reynolds, E. E., Campion and Parsons: The Jesuit Mission of 1580 (London: Sheed and Ward, 1980)

Rice, Louise, 'Jesuit Thesis Prints and the Festive Academic Defence at the Collegio Romano', in John W. O’Malley, S.J., Gauvin Alexander Bailey, et al., (eds), The 
Jesuits: Cultures, Sciences, and the Arts 1540-1773 (Toronto: University of Toronto Press, 1999), pp. 148-69

Richeôme, Louis, La peinture spirituelle (Lyon, 1611)

Robertson, Jean (ed.), Nicholas Breton: Poems Not Hitherto Printed (Liverpool: Liverpool University Press, 1967, first published 1952)

Rogers, D. M. (ed.), English Recusant Literature, 1538-1640 (London: Scolar Press, 1974)

Ross, Andrew C., 'Alessandro Valignano: The Jesuits and Culture in the East', in John W. O'Malley, S.J., Gauvin Alexander Bailey, et al., (eds), The Jesuits: Cultures, Sciences, and the Arts 1540-1773 (Toronto: University of Toronto Press, 1999), pp. 336-51

Rowe, Katherine, Dead Hands: Fictions of Agency, Renaissance to Modern (Stanford, CA: Stanford University Press, 1999)

Rowse, A. L., The Elizabethan Renaissance: The Life of the Society (Harmondsworth: Penguin, 2000)

Ruff, Lilian M., and Arnold Wilson, 'The Madrigal, the Lute Song and Elizabethan Politics', Past Q Present, 44 (1969), 3-51

Sams, Eric, The Real Shakespeare: Retrieving the Early Years 1564-1594 (New Haven: Yale University Press, 1995)

Saward, John, The Beauty of Holiness and the Holiness of Beauty: Art, Sanctity and the Truth of Catholicism (San Francisco: Ignatius Press, 1997)

Scallon, Joseph D., The Poetry of Robert Southwell, S.J. (Salzburg: Institut für Englische Sprache und Literatur, 1975)

Schoenfeldt, Michael C., Bodies and Selves in Early Modern England, Cambridge Studies in Renaissance Literature and Culture Series, 34 (Cambridge: Cambridge University Press, 1999)

Schroeder, H. J. (trans.), Canons and Decrees of the Council of Trent (Rockford, IL: Tan Books, 1982)

Sharp, Sir Cuthbert (ed.), The Rising in the North: The ${ }_{15} 6 \mathrm{~g}$ rebellion, being a reprint of the 'Memorials of the rebellion of the Earls of Northumberland and Westmoreland' (1840), with a new foreword by Robert Wood (Durham: J. Shotton, 1975; facsimile repr.)

Sheavyn, Phoebe, The Literary Profession in the Elizabethan Age; nnd edn, rev. J. W. Saunders (Manchester: Manchester University Press, 1967)

Shell, Alison, Catholicism, Controversy and the English Literary Imagination 15581660 (Cambridge: Cambridge University Press, 1999)

— 'Sources for the Study of Recusant Literary Culture', unpublished conference paper, Recusant Archives and Remains from the Three Kingdoms 1560-1789: Catholics in Exile at Home and Abroad (Downside Abbey, 2004)

'“We are Made a Spectacle": Campion's Dramas', in Thomas M. McCoog, S.J. (ed.), The Reckoned Expense: Edmund Campion and the Early English Jesuits (Woodbridge: Boydell, 1996), pp. 103-18

Shuger, Debora, Habits of Thought in the English Renaissance: Religion, Politics and the Dominant Culture (Berkeley: University of California Press, 1990)

— Renaissance Bible: Scholarship, Sacrifice and Subjectivity (Berkeley: University of California Press, 1999)

Simon, Joan, Education and Society in Tudor England (Cambridge: Cambridge University Press, 1967) 


\section{Bibliography}

Sinfield, Alan, Literature in Protestant England 1560-1660 (Beckenham: Croom Helm, 1983)

Smialkowska, Monika, 'Skipping Sports and Solemn Rites: Popular and High Culture in the Early Stuart Court Masque', unpublished doctoral thesis (University of Gloucester, 2001)

Smith, Bruce, Homosexual Desire in Shakespeare's England (Chicago: University of Chicago Press, 1991)

Smith, Jeffrey Chipps, 'The Art of Salvation in Bavaria', in John W. O’Malley, S.J., and Gauvin Alexander Bailey, et al., The Jesuits: Cultures, Sciences, and the Arts 1540-1773 (Toronto: University of Toronto Press, 1999), pp. 568-99

- Sensuous Worship: Jesuits and the Art of the Early Catholic Reformation in Germany (Princeton, NJ: Princeton University Press, 2002)

Smith, Lacey Baldwin, Elizabeth Tudor: Portrait of a Queen (London: Hutchinson, 1976)

Stone, Lawrence, Crisis in the Aristocracy 1558-1641 (Oxford: Oxford University Press, 1967)

Strong, Roy, The Cult of Elizabeth: Elizabethan Portraiture and Pageantry (London: Pimlico, 1999)

- Gloriana: The Portraits of Queen Elizabeth I (London: Pimlico, 2003) The Spirit of Britain: A Narrative History of the Arts (London: Pimlico, 1999)

Stukenbrock, Christiane, and Barbara Töpper (eds), 1000 Masterpieces of European Painting from 1300 to 1850 (Cologne: Könemann, 2000)

Suárez, Francisco, Of Laws and God the Lawgiver (De legibus ac deo legislatore) (New York: Wiley, 1964)

Sutton, Dana F. (ed.), Unpublished Works by William Alabaster, Salzburg Studies in English Literature Series: Elizabethan and Renaissance Studies, 126 (Salzburg: University of Salzburg, 1997)

Swain, Margaret, Needlework of Mary Queen of Scots (New York: Van NostrandReinhold, 1973)

Sweeney, Anne, 'Robert Southwell's English Lyrics: Authorial Integrity on the Mission to Elizabethan England (1580-1595)', unpublished doctoral thesis (Lancaster University, 2004)

Teresa of Jesus, St, Obres de Sta Teresa de Jesús, ed. el p. Silverio de Santa Teresa, Biblioteca Mistica Carmelitana Seriès, 1 (Burgos: Tip. de 'El Monte Carmelo', 1915-24)

Thomas, Paul, Authority and Disorder in Tudor Times 1485-1603 (Cambridge: Cambridge University Press, 1999)

Thorne, Alison, Vision and Rhetoric in Shakespeare: Looking through Language (Basingstoke: Macmillan, 2000)

Tottel, Richard (ed.), Tottel's Miscellany 1557: Songs and Sonnets (London: 1557; repr. London and Menston: Scolar Press, 1970)

Turnbull, W. B. (ed.), Rev. Robert Southwell: The Poetical Works (British Library 2340.a.2. in 'Old Authors, 1856 , etc.')

Tuve, Rosamund, 'Sacred "Parody" of Love Poetry, and Herbert', Studies in the Renaissance, 8 (1961), 250

Valone, Carolyn, 'Women on the Quirinal Hill: Patronage in Rome, 1560-1630', Art Bulletin, 36 (1994), 129-46

Vickers, Brian (ed.), Francis Bacon (Oxford: Oxford University Press, 1996) 
Waller, Gary, English Poetry of the Sixteenth Century (Harlow: Longman, 1986)

Wallerstein, Ruth, Studies in Seventeenth Century Poetic (Madison: University of Wisconsin Press, 1965)

Walsham, Alexandra, Church Papists: Catholicism, Conformity and Confessional Polemic in Early Modern England (Woodbridge: Boydell, 1993)

' 'Miracles and the Counter-Reformation Mission to England', The Humanities Journal, 46 (2003), 779-815

Warhol, Robyn R., and Diane Price Herndl (eds), Feminisms: An Anthology of Literary Theory and Criticism (New Brunswick: Rutgers University Press, 1991)

Warnlop, Jessica Jean, 'The Influence of Giordano Bruno on the Writings of Sir Philip Sidney’ (unpublished dissertation, Texas A\&M University, August 1973)

Watts, V. E., trans., Boethius: The Consolation of Philosophy (Harmondsworth: Penguin, 1969)

Waugh, Evelyn, Edmund Campion: Scholar, Priest, Hero, and Martyr (Oxford: Oxford University Press, 1980)

Wells, Robin Headlam, Spenser's Faerie Queene and the Cult of Elizabeth (Beckenham: Croom Helm, 1983)

Wells, Stanley (ed.), Shakespeare: A Bibliographical Guide (Oxford: Clarendon Press, 1990)

— and Gary Taylor (eds), The Oxford Shakespeare Complete Works (Oxford: Clarendon Press, 1988)

White, Helen C., Tudor Books of Saints and Martyrs (Madison: University of Wisconsin Press, 1963)

__ 'Southwell - Metaphysical and Baroque', Modern Philology, 61 (1963/4), 159-68

Willcock, Gladys Doidge, and Alice Walker (eds), George Puttenham: The Arte of English Poesie (London: R. Field, 1589; repr. London: Cambridge University Press, 1970)

Williams, Michael E., 'Campion and the English Continental Seminaries', in Thomas M. McCoog, S.J. (ed.), The Reckoned Expense: Edmund Campion and the Early English Jesuits (Woodbridge: Boydell, 1996), pp. 285-99

— The Venerable English College Rome: A History 1579-1979 (London: Associated Catholic Publications (on behalf of the College), 1979)

Williamson, Claude, Letters from the Saints: Early Renaissance and Reformation Periods from St. Thomas Aquinas to Bl. Robert Southwell (London: Rockliff, 1958)

Wilson, Richard, 'A Bloody Question: The Politics of Venus and Adonis' (unpublished lecture, Sorbonne, 1998)

- Secret Shakespeare: Studies in Theatre, Religion and Resistance (Manchester: Manchester University Press, 2004)

— 'Shakespeare and the Jesuits', Times Literary Supplement, 19 December 1997, $11-13$

- Will Power: Essays on Shakespearean Authority (London: Harvester Wheatsheaf, 1993)

Wilson, Scott, 'The Struggle for Sovereignty in Astrophil and Stella', Criticism, 33.3 (Summer 1991), 309-32

Wormald, Jenny, Mary Queen of Scots: Politics, Passion and a Kingdom Lost, rev. edn (London: Taurus Parke, 2001)

- Mary Queen of Scots: A Study in Failure (London: Collins \& Brown, 1991)

Woudhuysen, H. R., Sir Philip Sidney and the Circulation of Manuscripts, 1558-1640

(Oxford: Clarendon Press, 1996) 


\section{Bibliography}

— (ed.), The Penguin Book of Renaissance Verse 1509-1659 (Harmondsworth: Penguin, 1993)

Yates, Frances, The Occult Philosophy in the Elizabethan Age (London: Routledge \& Kegan Paul, 1979)

_ Giordano Bruno and the Hermetic Tradition (London: Routledge \& Kegan Paul, 1971)

de Yepes, Diego, Historia particular de la persecution de Inglaterre (Madrid, 1599), ed.

D. M. Rogers (Farnborough: Gregg, 1971)

Young, William J., S.J. (ed. and trans.), St Ignatius of Loyola: Letters (Chicago, IL: Loyola University Press, 1959)

Zeri, Federico, Pittura e controriforma: l'arte senza tempo di Scipione da Gaeta, repr.

(Vicenza: Neri Pozzone, c.1997)

\section{INTERNET SOURCES}

http://apm.brookes.ac.uk/publishing/contexts/elizabet/mechanis.htm www.catholic-forum.com/saints/prayoo $55 \cdot \mathrm{htm}$

www.ccel.org/ccel/calvin/calcom.html www.cuencanet.com/ortiz/chinchona.htm www.eebo.chadwyck.com/home www.faculty.fairfield.edu/jmac/nadal/nadalintro.htm www.jesuit.org www.nationaltrust.org.uk/places/lyvedennewbield/history_papers.html www.newadvent.org/cathen.htm www.noosphere.cc/flandersScientists.html www.philological.bham.ac.uk/minutum/intro.html www.rembert-dodoens.biography.ms www.sjweb.info/articles/rometour_all.cfm www.tudorplace.com.htm www.walsingham.org 